\title{
PENGARUH PENAMBAHAN ABU AMPAS TEBU DAN KAPUR TERHADAP KARAKTERISTIK TANAH LEMPUNG EKSPANSIF (STUDI KASUS : TANAH DI BOJONEGORO)
}

\author{
Yanwar Eko Prasetyo $^{1^{*}}$, Yulvi Zaika ${ }^{2}$, Arief Rachmansyah ${ }^{2}$ \\ ${ }^{1}$ Mahasiswa / Program Studi Sarjana Teknik Sipil Fakultas Teknik / Universitas Brawijaya \\ ${ }^{2}$ Dosen / Jurusan Teknik Sipil Fakultas Teknik / Universitas Brawijaya \\ Korespondensi: m.engyeko@gmail.com
}

\begin{abstract}
In each region having different types of soil, one type of soil is expansive clay. In Indonesia, more than 1/5 of the land area in Indonesia are an expansive clay. This type of soil will affected by changes in water content and experience significant shrinkage. Therefore, to improve the soil and minimize shrinkage growth, an effort is needed, one of which is soil stabilization. Physical testing of soil with soil samples in the district Ngasem, Kab. Bojonegoro which is expansive clay soil shows that the CBR value is $3.953 \%$, and the swelling value is $6.1858 \%$. With such physical conditions with low carrying capacity it is necessary to stabilize the soil on clay in Bojonegoro. Stabilization efforts carried out are by chemical stabilization by mixing soil samples with additives in the form of bagasse and lime ash. The results of the physical soil test from the preliminary research conducted by the author by mixing bagasse ash in the soil with variations in levels of $8 \%, 10 \%, 12 \%, 14 \%$ showed a mixture of $8 \%$ bagasse ash was the optimum level for repairs to the soil. So it is used a mixture of $8 \%$ bagasse ash with the addition of variations in lime content of $4 \%, 6 \%$ and $8 \%$ of the total weight of the mixture. A mixture of $8 \%$ bagasse ash and $6 \%$ lime content produced a CBR value of $9,324 \%$, this CBR value increased to $135.87 \%$. While the swelling value is $0.1681 \%$, with the same mixture level. This swelling value decreased to $97.28 \%$. For the value of free development it decreased to $217.7 \%$ from the previous one which amounted to $70.59 \%$ to $22.22 \%$.
\end{abstract}

Keywords: Bojonegoro Expansion Clay Ground, Soil Stabilization, Sugar Cane Ash, Lime, CBR, Swelling

\section{PENDAHULUAN}

Komposisi dan karakteristik tanah bervariasi tergantung pada ketinggian, kontur tanah, letak suatu daerah serta kandungan unsur hara dan teksturnya sehingga daya dukung yang dimiliki tanah berbeda-beda pada satu lokasi dengan lokasi yang lain. Daya dukung tanah lempung ekspansif sangat rendah dan memiliki sensitifitas serta kembang susut yang tinggi jika terjadi perubahan kadar air. Hal ini akan mempengaruhi keadaan struktur dan menimbulkan kerusakan pada tanah tersebut.

Banyak penelitian telah dilakukan untuk mendapatkan kondisi tanah yang lebih stabil pada tanah ekspansif dengan cara stabilisasi kimia, yaitu dengan mencampur tanah ekspansif dengan zat adiftif [1][2]. Penggunaan zat aditif untuk stabilisasi tanah ekspansif dapat berupa bahan industrial seperti kapur, semen, dan gypsum. Zat aditif lain yang dapat digunakan yang merupakan limbah suatu proses produksi seperti abu sekam padi, abu ampas tebu, fly ash dan lain-lain.

Penelitian ini akan melakukan uji sifat fisik tanah, uji daya dukung tanah dan uji pengembangan tanah. Sampel tanah yang digunakan adalah tanah dari Kecamatan Ngasem Kabupaten Bojonegoro, Jawa Timur. Berdasarkan penelitian Febra Ndaru [3], tanah lempung ekspansif Bojonegoro dapat dikelompokkan tanah tersebut merupakan tanah lempung ekspansif dengan potensi mengembang tinggi, derajat mengembang yang kritis dan berplastisitas tinggi.

Zat aditif yang digunakan pada penilitian ini adalah abu ampas tebu dan kapur dengan kadar $8 \%$ abu ampas tebu dan penambahan variasi kadar kapur 4\%, 6\% dan $8 \%$ dari berat total campuran. 
berikut:

Tujuan dari penelitian ini sebagai

1. Untuk mengetahui pengaruh dari penambahan campuran abu ampas tebu dan kapur terhadap karakteristik tanah lempung ekspansif di Bojonegoro ( liquid limit, plastic limit, plastic index, spesific grafity, $\gamma d$, dan kadar air optimum ).

2. Untuk mengetahui pengaruh dari penambahan campuran abu ampas tebu dan kapur terhadap nilai CBR (California Bearing Ratio) tanah lempung ekspansif, dan untuk mengetahui prosentase campuran optimum yang menghasilkan CBR maksimum.

3. Untuk mengetahui pengaruh dari penambahan campuran abu ampas tebu terhadap nilai pengembangan (swelling) tanah lempung ekspansif, dan untuk mengetahui prosentase campuran optimum yang menghasilkan (swelling) minimum.

4. Untuk mengetahui pengaruh dari penambahan campuran abu ampas tebu terhadap nilai pengembangan bebas (free swell) tanah lempung ekspansif, dan untuk mengetahui prosentase campuran optimum yang menghasilkan pengembangan bebas minimum.

5. Untuk mengetahui pengaruh nilai batas cair terhadap sifat kemampatan tanah.

\section{TINJAUAN PUSTAKA}

\subsection{Tanah lempung}

Tanah lempung adalah partikel mineral berkerangka dasar silikat yang berdiameter kurang dari 4 micrometer. Lempung mengandung leburan silika dan/atau aluminiumyang halus. Unsur-unsur ini, silikon, oksigen, dan aluminum adalah unsur yang paling banyak menyusun kerak bumi. Lempung terbentuk dari proses pelapukan batuan silika oleh asam karbonat dan sebagian dihasilkan dari aktivitas panas bumi.

Lempung membentuk gumpalan keras saat kering dan lengket apabila basah terkena air. Sifat ini ditentukan oleh jenis mineral lempung yang mendominsasinya.

Klasifikasi tanah tidak berdasarkan hanya dengan ukurannya saja, namun juga dengan kandungan mineral-mineral yang ada pada tanah tersebut. Jadi walaupun ukuran partikel seperti tanah lempung tanah tersebut belum tentu termasuk jenis tanah lempung jika belum diketahui mineral-mineral didalamnya.
Tabel 1. Penggolongan Tanah Oleh Beberapa Lembaga Berdasarkan Ukuran Butir

\begin{tabular}{|l|c|c|c|c|}
\hline \multirow{2}{*}{ Nama Golongan } & \multicolumn{4}{|c|}{ Ukuran Butiran (mm) } \\
\cline { 2 - 5 } & Kerikil & Pasir & Lanau & Lempung \\
\hline $\begin{array}{l}\text { Massachusetts } \\
\text { Institute of } \\
\text { Technology (MIT) }\end{array}$ & $>2$ & $2-0,06$ & $0,06-0,002$ & $<0,002$ \\
\hline $\begin{array}{l}\text { U.S. Department od } \\
\text { Agriculture (USDA) }\end{array}$ & $>2$ & $2-0,05$ & $0,05-0,002$ & $<0,002$ \\
\hline $\begin{array}{l}\text { American } \\
\text { Association of State }\end{array}$ & $76,2-2$ & $2-0,075$ & $0,075-0,002$ & $<0,002$ \\
$\begin{array}{l}\text { Highway and } \\
\text { Transportation } \\
\text { Offical (AASHTO) }\end{array}$ & & & & \\
\hline $\begin{array}{l}\text { Unified Soil } \\
\text { Classification } \\
\text { System (USCS) }\end{array}$ & $76,2-4,75$ & $4,75-0,075$ & & $<0,0075$ \\
\hline
\end{tabular}

\subsection{Mineral dalam tanah lempung}

Kelompok mineral tanah lempung diantaranya: montmorillonite, illite, kaolinite, dan polygorskite [4]. Mineral-mineral tersebut memiliki struktur lapisan serta ion penghubung yang berbeda sehingga tingkat plastisitas dan potensi pengembangan yang dihasilkan juga berbeda. Susunan mineral pada tanah lempung ekspansif mempunyai karakter kembang dan susut yang drastis apabila terjadi perubahan kadar air seperti pada kelompok montmorillonite. Sehingga kestabilan tanah pada kelompok ini sangat dipengaruhi oleh kadar air.

Pada penelitian yang dilakukan, usaha stabilisasi tanah yang digunakan adalah stabilisasi mekanik dan kimia dengan menggunakan penambahan zat aditif. Zat aditif yang digunakan yaitu berupa abu ampas tebu dan kapur [5]. Abu ampas tebu dapat berfungsi sebagai filler yang bertujuan untuk mengisi pori antar butiran tanah agar tanah lebih stabil. Sedangkan kapur berfungsi sebagai peningkat sifat pozzolanic yang ada pada abu ampas tebu yang dirasa masih kurang karena kandungan $\mathrm{Ca}$ yang sedikit. Kandungan abu ampas tebu adalah seperti yang ditampilkan Tabel 2 .

\subsection{Atterberg Limit}

Atterberg Limit adalah kondisi transisi tanah berbutir halus pada kadar air tertentu. Berdasaarkan pada jumlah air pada tanah, tanah dapat dipisahkan dalam 4 keadaan dasar : solid, semi-solid, plastis, dan cair. Dan batas-batas antara keadan tersebut adalah batas cair (liquid limit), baas plastis (plastic limit) dan batas susut (shrinkage limit). 
Tabel 2. Hasil Analisis Kandungan dalam Abu Ampas Tebu

(Sumber: Laboratorium UPT Layanan Analisa dan Pengukuran, Malang)

\begin{tabular}{|c|c|c|c|c|c|}
\hline \multirow{2}{*}{ No } & \multirow{2}{*}{$\begin{array}{l}\text { Para } \\
\text { meter }\end{array}$} & $\begin{array}{l}\text { Hasil } \\
\text { Analisis }\end{array}$ & \multicolumn{3}{|c|}{ Metode Analisis } \\
\hline & & Kadar & Satuan & Pereaksi & Metode \\
\hline 1. & $\mathrm{Si}$ & $\begin{array}{l}25,07 \\
+0,02\end{array}$ & $\%$ & Aquaregia & Gravimetri \\
\hline 2. & $\mathrm{Al}$ & $\begin{array}{l}0,11 \quad+ \\
0,00\end{array}$ & $\%$ & $\begin{array}{l}\text { Aquaregia- } \\
\text { Aluminon }\end{array}$ & $\begin{array}{l}\text { Spektrofoto } \\
\text { metri }\end{array}$ \\
\hline 3. & $\mathrm{Fe}$ & $\begin{array}{l}0,13 \quad+ \\
0,00\end{array}$ & $\%$ & $\mathrm{HNO}_{3}$ & AAS \\
\hline 4. & $\mathrm{Ca}$ & $\begin{array}{l}0,15 \\
0,00\end{array}$ & $\%$ & $\mathrm{HNO}_{3}$ & AAS \\
\hline 5. & $\mathrm{Mg}$ & $\begin{array}{l}0,76 \quad+ \\
0,00\end{array}$ & $\%$ & $\mathrm{HNO}_{3}$ & AAS \\
\hline
\end{tabular}

Indeks plastisitas adalah selisih batas cair dan batas plastis (masih bersifat plastis), karena itu menunjukkan sifat keplastisan tanah.

Compression index $(\mathrm{Cc})$ ialah angka yang menentukan kemampuan contoh tanah untuk mengalami pemampatan yang dipakai untuk menghitung penurunan. Nilai Compression index $(\mathrm{Cc})$ ini ditinjau dari besarnya kadar air pada liquid limit.

Tabel 3. Hubungan untuk Indeks Pemampatan $\mathrm{Cc}$

\begin{tabular}{|c|c|c|}
\hline Persamaan & Acuan & Daerah pemalaian \\
\hline$C_{c}=0,007(1 \mathrm{~L}-7)$ & Skempton & Lenping yang terbentuk kembail (temoided) \\
\hline $\mathrm{Cc}_{\mathrm{c}}=0,01 \mathrm{WN}$ & & Lenpurg Chicago \\
\hline$C_{c}=1,15\left(\theta_{2}-0,27\right)$ & Nishida & Semua lemprng \\
\hline$C_{c}=0,30\left(e_{2}-0,27\right)$ & Hongh & $\begin{array}{l}\text { Tamah kodesif anorganik lanan, lempung berianou, } \\
\text { lempung }\end{array}$ \\
\hline$C_{c}=0,0115 \mathrm{WN}$ & & Tanah organik, gambut, lanan orgarik, dan leapurg \\
\hline$C_{c}=0,0446(1 \mathrm{~L}-9)$ & & Lempung Branila \\
\hline$C_{c}=0,75\left(t_{2}-0,5\right)$ & & Tanah dengan plastisitas rendah \\
\hline$C_{c}=0,2088 \mathrm{e}_{2}+0,0083$ & & Lenpureg Caicago \\
\hline$C_{c}=0.156 \mathrm{e}_{2}+0.0107$ & & Semua lempung \\
\hline
\end{tabular}

\subsection{California Bearing Ratio (CBR)}

California Bearing Ratio (CBR) didefinisikan sebagai suatu perbandingan antara beban penetrasi suatu bahan terhadap bahan standard dengan kedalaman dan kecepatan penetrasi yang sama dan dinyatakan dalam persen.

Harga CBR dihitung pada harga penetrasi 0,1 dan 0,2 inchi, dengan cara membagi beban pada penetrasi ini masingmasing dengan beban sebesar 3000 dan 4500 pound.

\subsection{Pengembangan (Swelling)}

Swelling adalah bertambahnya volume tanah secara perlahan-lahan akibat tekanan air pori berlebih negatif. Tanah yang banyak mengandung lempung khususnya tanah lempung ekspansif mengalami perubahan volume yang ekstrim ketika kadar air berubah.

\section{METODE PENELITIAN}

Metode dalam penelitian yang dilakukan adalah sebagai berikut:

1. Pemeriksaan Berat Jenis Sampel (ASTM 1989 D 854-83)

2. Pemeriksaan Batas Konsistensi Sampel (ASTM 1989 D 4318)

3. Pengujian Proktor Standart (ASTM D-698 (Metode B))

4. Pengujian CBR (ASTM D-1883)

5. Pengujian Swelling (ASTM D-4546-90)

Benda uji yang digunakan adalah tanah asli dari daaerah Kecamatan Ngasem, Kabupaten Bojonegoro, Jawa Timur, serta campuran tanah asli dengan abu ampas tebu dan kapur. Persentase abu ampas tebu yang digunakan adalah $8 \%$ dengan variasi kadar kapur 4\%, 6\% dan $8 \%$ dari berat total campuran. Berikut adalah bagan alir dari penelitian ini (Gambar 1).

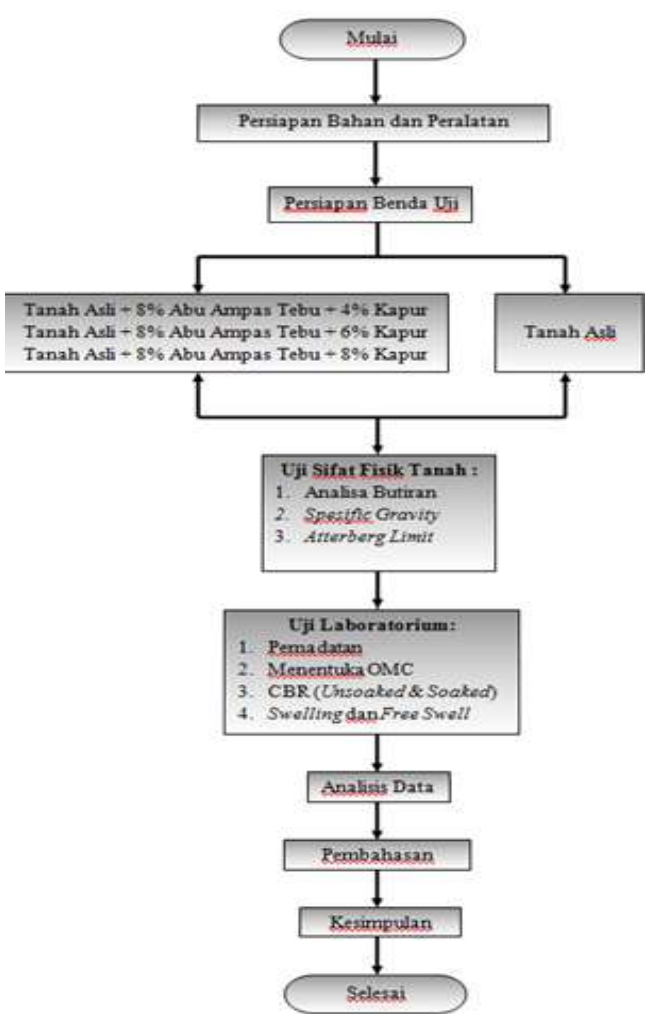

Gambar 1. Diagram alur penelitian 


\section{HASIL DAN PEMBAHASAN}

\subsection{Pemeriksaan Specific Gravity}

Nilai specific gravity abu ampas tebu adalah 2,071 dan untuk kapur sebesar 2,39. Penambahan campuran kedua bahan tersebut dapat menurunkan nilai specific gravity tanah asli. Hasil dari pemeriksaan specific gravity ditampilkan dalam Gambar 2.

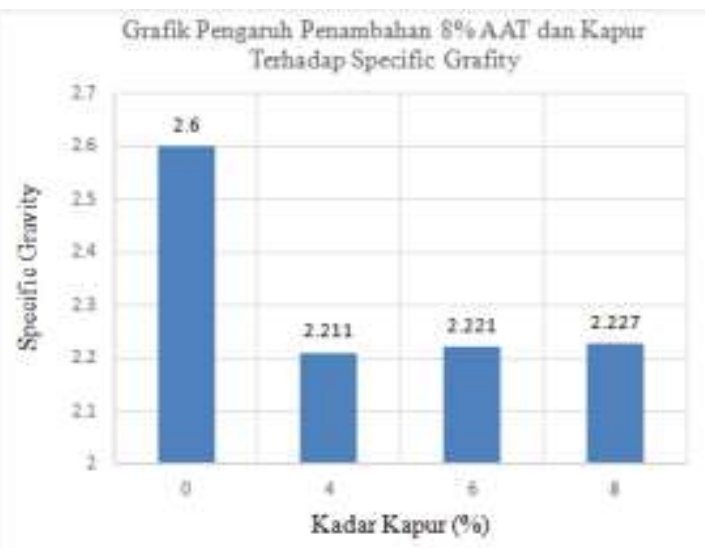

Gambar 2. Grafik Pengaruh Penambahan Abu Ampas Tebu dan Kapur Terhadap Specific Gravity

\subsection{Klasifikasi Tanah}

\subsubsection{Analisis saringan dan hidrometer}

Analisis saringan dan hydrometer ini bertujuan untuk menentukan jenis tanah berdasarkan butiran.

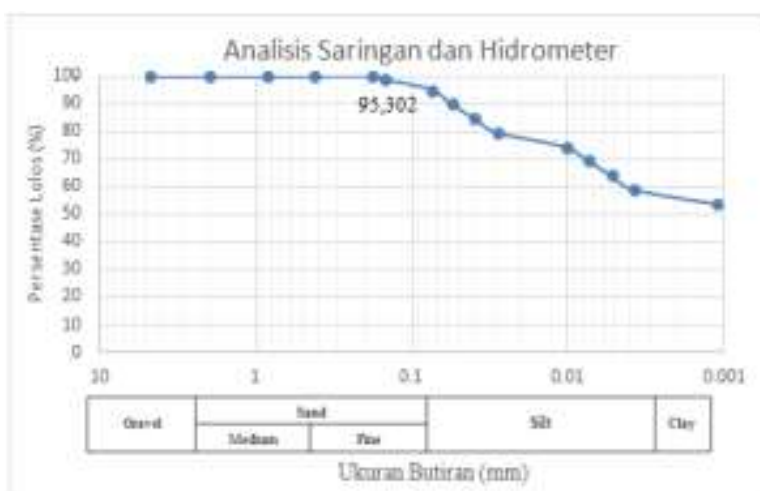

Gambar 3. Grafik Hasil Analisis Saringan dan Hidrometer

(Sumber : Benny Tobing, dkk, 2014)

Hasil analisis menunjukkan bahwa tanah dari Kecamatan Ngasem, Kabupaten Bojonegoro ini memiliki persentase distribusi lolos saringan no. 200 sebesar 95,30\%, dan menurut sistem klasifikasi tanah USCS
(Unified Soil Classification System) tanah tersebut termasuk jenis tanah berbutir halus.

\subsubsection{Pemeriksaan Batas-batas Atterberg}

Hasil dari pengujian batas-batas Atterberg ditampilkan pada Tabel 4.

Tabel 4. Hasil Pengujian Batas Atterberg

\begin{tabular}{|l|l|l|l|l|}
\hline $\begin{array}{l}\text { KOMPOSISI } \\
\text { TANAH }\end{array}$ & $\begin{array}{l}\text { LL } \\
(\%)\end{array}$ & $\begin{array}{l}\text { PL } \\
(\boldsymbol{\%})\end{array}$ & $\begin{array}{l}\text { SL } \\
(\boldsymbol{\%})\end{array}$ & $\begin{array}{l}\text { PI } \\
(\boldsymbol{\%})\end{array}$ \\
\hline Tanah Asli & 104 & 44.41 & 2.8 & 59.59 \\
\hline $\begin{array}{l}\text { Tanah Asli + } \\
\text { 8\%aat+4\%kapur }\end{array}$ & 60.71 & 50.72 & 38.68 & 9.99 \\
\hline $\begin{array}{l}\text { Tanah Asli + } \\
\text { 8\%aat+6\%kapur }\end{array}$ & 61.87 & 50.00 & 41.87 & 11.87 \\
\hline $\begin{array}{l}\text { Tanah Asli + } \\
\text { 8\%aat+8\%kapur }\end{array}$ & 61.20 & 47.91 & 47.74 & 13.29 \\
\hline
\end{tabular}

Dari Tabel 4 dapat dilihat bahwa nilai indeks plastisitas menurun jika dibandingkan dengan tanah asli. Hal tersebut dapat terjadi karena ion $\mathrm{Ca}^{+}$dari kapur tertarik oleh tanah lempung ekspansif yang bermuatan negative sehingga menyebabkan sifat ekspansifitas berkurang dan menurunnya indeks plastisitas. Sebab lain, disebabkan oleh sifat abu ampas tebu yang dapat mengisi pori-pori dari butiran tanah.

\subsubsection{Sistem Klasifikasi Tanah Sistem Unified}

Nilai analisis butiran tanah lolos saingan no. 200 sebesar 95,3024\%, dengan Indeks Plastisitas sebesar 59,59\%. Maka klasifikasi tanah berdasarkan sistem unified, tanah tersebut diklasifikasikan sebagai tanah $\mathrm{CH}$ (lempung anorganik dengan plastisitas tinggi) dapat dilihat pada Gambar 4.

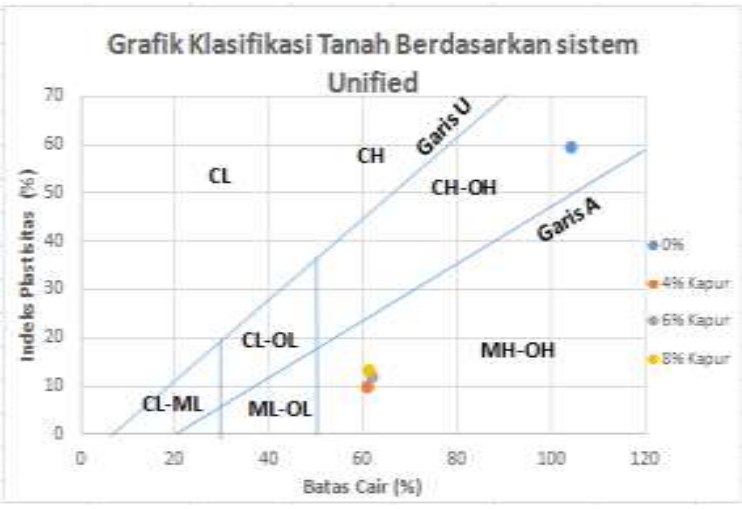

Gambar 4. Grafik Sistem Klasifikasi Tanah berdasarkan Sistem Unified 


\subsubsection{Sistem Klasifikasi Tanah AASHTO}

Dari hasil analisa saringan dan hydrometer serta uji batas-batas Atterberg, berdasarkan sistem klasifikasi tanah AASHTO maka tanah lempung tersebut tergolong tanah kelompok A-7-5 yaitu $\mathrm{PI} \leq \mathrm{LL}-30$.

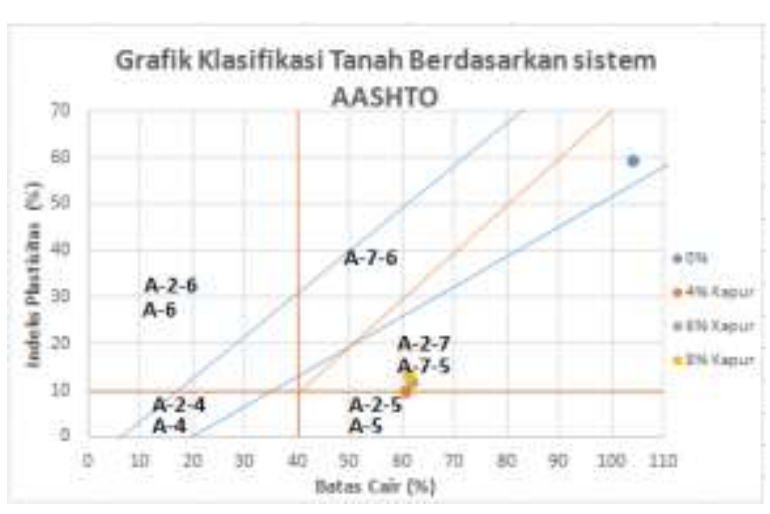

Gambar 5. Grafik Sistem Klasifikasi Tanah berdasarkan Sistem AASHTO

\subsubsection{Pendekatan Empiris untuk Indeks Pemampatan (Cc)}

Persamaan empiris indeks pemampatan

(Cc) digunakan untuk memperkirakan penurunan pondasi secara kasar sebelum pengujian laboratorium dilakukan. Hasil dari persamaan tersebut dapat dilihat pada Tabel 5.

Tabel 5. Indeks Pemampatan

\begin{tabular}{|l|l|l|}
\hline KOMPOSISI TANAH & LL & Cc \\
\hline Tanah Asli & 104 & 0.6580 \\
Tanah Asli + 8\% AAT + & 60.71 & 0.3550 \\
$\begin{array}{l}\text { 4\% Kapur } \\
\text { Tanah Asli + 8\% AAT + } \\
\text { 6\% Kapur } \\
\text { Tanah Asli + 8\% AAT + } \\
\text { 8\% Kapur }\end{array}$ & 61.87 & 0.3631 \\
\hline
\end{tabular}

Dari hasil perhitungan diatas menunjukkan bahwa campuran tersebut dapat dapat memperkecil kemampuan tanah lempung ekspansif untuk memampat, sehingga penurunan dari tanah lempung ekspansif juga akan semakin kecil.

\subsection{Sifat Ekspansifitas}

Nilai aktivitas tanah dapat digunakan untuk mengetahui potensi pengembangan. Tanah lempung ekspansif di Bojonegoro potensi mengembangnya termasuk dalam kategori very high karena memiliki IP sebesar
59,59\%. Untuk tanah campuran dengan zat aditif dapat dilihat pada Tabel 6.

Tabel 6. Nilai Aktivitas Tanah Lempung Ekspansif dan Tanah Campuran

\begin{tabular}{|l|l|l|}
\hline KOMPOSISI TANAH & PI & Activity \\
\hline Tanah Asli & 59.59 & 1.1033 \\
\hline $\begin{array}{l}\text { Tanah Asli + 8\% AAT + 4\% } \\
\text { Kapur }\end{array}$ & 9.99 & 0.1850 \\
\hline $\begin{array}{l}\text { Tanah Asli + 8\% AAT + 6\% } \\
\text { Kapur }\end{array}$ & 11.87 & 0.2198 \\
\hline $\begin{array}{l}\text { Tanah Asli + 8\% AAT + 8\% } \\
\text { Kapur }\end{array}$ & 13.29 & 0.2461 \\
\hline
\end{tabular}

Dari hasil perhitungan dengan menggunakan persamaan, didapatkan plot data sehingga mendapatkan hasil low-medium pada swelling potential sampel tanah campuran sesuai pada Gambar 6.

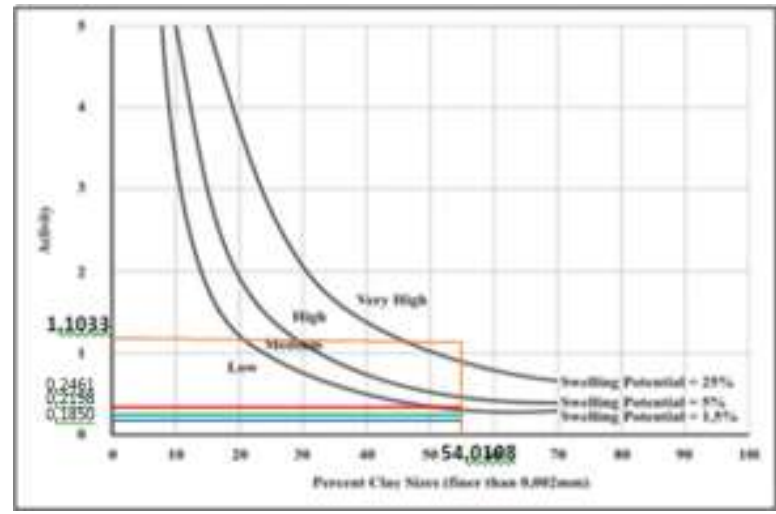

Gambar 6. Klasifikasi swelling potensial

\subsection{Pemeriksaan Pemadatan Standar}

Tujuan dari uji pemadatan adalah untuk mengetahui nilai kadar air optimum dan berat isi kering maksimum. Hasil pengujian pemadatan standar pada tanah asli dan tanah yang sudah dicampur dengan bahan stabilisasi berupa abu ampas tebu dan variasi kadar kapur dapat dilihat pada Gambar 7.

Gambar 7 menunjukkan bahwa campuran tersebut dapat mempengaruhi OMC dari tanah asli serta berat isi keringnya. Untuk lebih detailnya dapat dilihat pada Tabel 10.

Setelah dicampur dengan abu ampas tebu dan dipadatkan, ruang pori tanah yang sebelumnya berupa rongga udara akan terisi oleh butiran abu ampas tebu sehingga tanah menjadi lebih padat. Berat isi kering menurun akibat berat campuran yang lebih ringan 
daripada berat butiran tanah dalam volume yang sama. Sehingga kebutuhan akan air meningkat dan mengakibatkan kadar air optimum juga meningkat seiring bertambahnya kadar kapur.

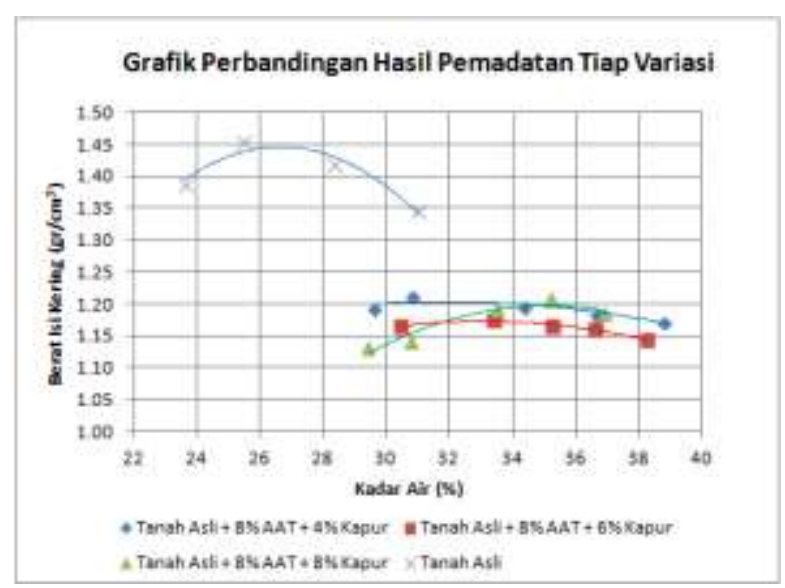

Gambar 7. Grafik Perbandingan Berat Isi Kering terhadap Kadar Air tiap Penambahan Abu Ampas Tebu dan Variasi Kadar Kapur

Tabel 7. Hasil Uji Pemadatan Standart

\begin{tabular}{|c|c|c|}
\hline \multirow[t]{2}{*}{$\begin{array}{l}\text { KOMPOSISI } \\
\text { TANAH }\end{array}$} & $\begin{array}{l}\text { KADAR AIR } \\
\text { OPTIMUM }\end{array}$ & $\begin{array}{l}\text { BERAT ISI } \\
\text { KERING } \\
\text { MAKSIMUM }\end{array}$ \\
\hline & $(\%)$ & $\left(\mathrm{gr} / \mathrm{cm}^{3}\right)$ \\
\hline Tanah Asli & 26,89 & 1,401 \\
\hline $\begin{array}{l}\text { Tanah } \quad \text { Asli }+ \\
8 \% \text { AAT }+4 \% \text { Kapur }\end{array}$ & 31.21 & 1.190 \\
\hline $\begin{array}{l}\text { Tanah } \quad \text { Asli }+ \\
8 \% \text { AAT }+6 \% \text { Kapur }\end{array}$ & 33.45 & 1.186 \\
\hline $\begin{array}{l}\text { Tanah } \quad \text { Asli }+ \\
8 \% \text { AAT }+8 \% \text { Kapur }\end{array}$ & 34.98 & 1.182 \\
\hline
\end{tabular}

\subsection{Pemeriksaan CBR Laboratorium}

Tujuan penelitian ini adalah untuk mengetahui daya dukung dari sampel tanah tersebut. Pada pengujian CBR ini dilakukan dalam dua keadaan yaitu CBR tak terendam (unsoaked) dan CBR terendam (soaked). Hasil dari pengujian CBR dapat dilihat pada Tabel 8. Nilai CBR meningkat disebabkan pengaruh pencampuran abu ampas tebu dan kapur akan menimbulkan reaksi pozzolanic, reaksi ini akan berakibat pada peningkatan daya ikat antar butiran tanah sehingga akan membentuk tanah yang lebih keras dan kaku.
Tabel 8. Hasil Pengujian CBR tak terendam (unsoaked)

\begin{tabular}{|l|l|l|}
\hline \multirow{2}{*}{ KOMPOSISI TANAH } & \multicolumn{2}{|c|}{ CBR } \\
\cline { 2 - 3 } & $\begin{array}{l}\text { UNSOAKED } \\
\%\end{array}$ & $\begin{array}{l}\text { SOAKED } \\
(\%)\end{array}$ \\
\hline Tanah Asli & 3.953 & 2.385 \\
\hline $\begin{array}{l}\text { Tanah Asli }+8 \% \text { Abu } \\
\text { Ampas Tebu +4\% Kapur }\end{array}$ & 6.216 & 5.561 \\
\hline $\begin{array}{l}\text { Tanah Asli + 8\% Abu } \\
\text { Ampas Tebu +6\% Kapur }\end{array}$ & 9.324 & 7.979 \\
\hline $\begin{array}{l}\text { Tanah Asli + 8\% Abu } \\
\text { Ampas Tebu + 8\% Kapur }\end{array}$ & 5.643 & 5.147 \\
\hline
\end{tabular}

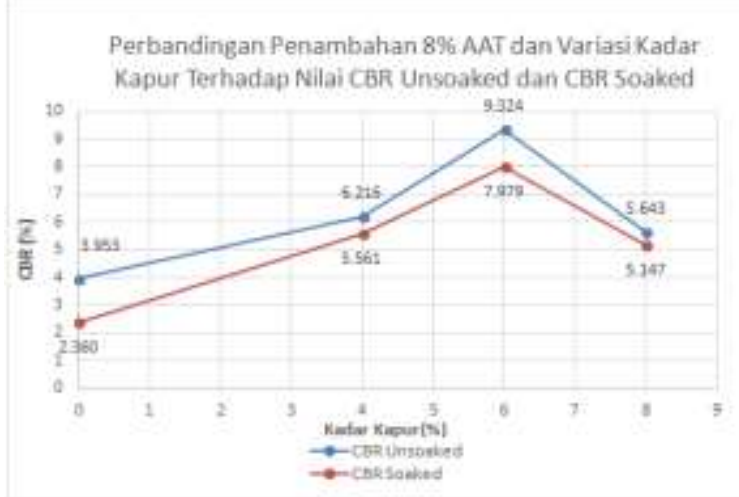

Gambar 8. Grafik Perbandingan Nilai CBR Tak Terendam (Unsoaked) dan Terendam (Soaked)

Nilai CBR terendam lebih rendah dari CBR tak terendam karena pada CBR terendam keadaan tanah dikondisikan seperti halnya di lapangan dan dalam keadaan jenuh sehingga kadar airnya meningkat dan melebihi kadar air optimum pada masing-masing campuran yang berakibat pada menurunnya daya dukung dari sampel tersebut.

\subsection{Pemeriksaan Pengembangan (Swelling)}

Tujuan dari uji pengembangan adalah untuk mengetahui tingkat pengembangan dari suatu tanah. Caranya adalah dengan membandingkan antara perubahan tinggi selama perendaman terhadap tinggi benda uji semula dan dinyatakan dalam persen (\%). Pengujian pengembangan (swelling) dilakukan pada sampel tanah dalam keadaan terendam air selama 52 jam. Hasil dari pengujian pengembangan ini dapat dilihat pada Tabel 9. 
Tabel 9. Hasil Pengujian Swelling

\begin{tabular}{|l|l|}
\hline \multicolumn{1}{|c|}{ Komposisi Bahan } & $\begin{array}{l}\text { Swell } \\
(\%)\end{array}$ \\
\hline Tanah asli & 6.1858 \\
\hline Tanah asli $+8 \%$ AAT $+4 \%$ Kapur & 0.2301 \\
\hline Tanah asli $+8 \%$ AAT $+6 \%$ Kapur & 0.2124 \\
\hline Tanah asli $+8 \%$ AAT $+8 \%$ Kapur & 0.1681 \\
\hline
\end{tabular}

Nilai swelling dari setiap campuran mengalami penurunan dengan semakin bertambahnya kadar kapur. Hal ini disebabkan penambahan abu ampas tebu mengakibatkan rongga yang ada pada butiran tanah akan tertutup oleh bahan-bahan tersebut (lebih padat). Sedangkan pada kapur dengan unsur $\mathrm{Ca}$ dalam kapur yang bermuatan positif akan ditarik oleh tanah lempung ekspansif yang bermuatan negative sehingga membuat tanah tersebut bermuatan netral dan membuat kemampuan tanah lempung ekspansif dalam menyerap air berkurang.

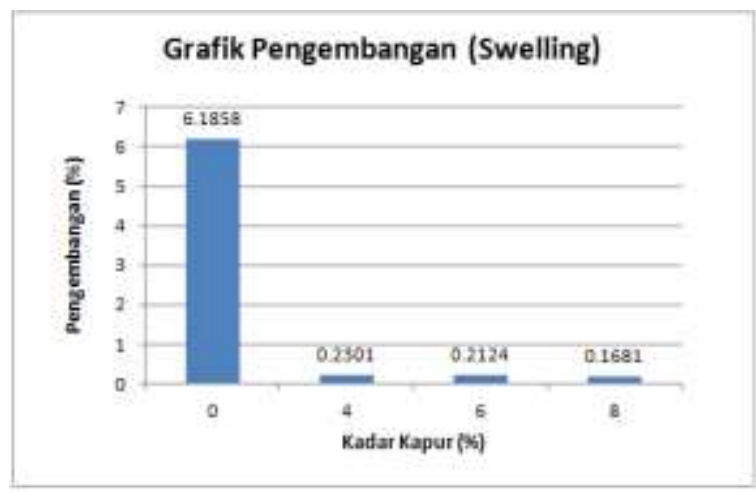

Gambar 9. Grafik Pengaruh Penambahan Kadar Abu Ampas Tebu 8\% dan Variasi Kadar Kapur terhadap Nilai Pengembangan

\subsection{Pengujian pengembangan bebas (Free Swell)}

Pengujian pengembangan bebas didefinisakan sebagai peningkatan volume tanah dari bentuk bubuk kering longgar ketika dituangkan ke dalam air, dan dinyatakan dalam persentase dari volume aslinya. Pada uji pengembangan bebas ini didapatkan hasil seperti tertera pada Tabel 10 dan Gambar 11.

Nilai pengembangan bebas lebih rendah dibandingkan tanah asli. Hal tersebut terjadi karena pori-pori tanah terisi oleh campuran sehingga butiran tanah menjadi lebih padat.
Selain itu pada sampel tanah tersebut terdapat $\mathrm{Ca}^{+}$yang ada pada kapur dan akan ditarik oleh tanah lempung ekspansif yang bermuatan negative sehingga membuat kemampuan tanah lempung ekspansif dalam menyerap air berkurang. Pengembangan bebas (free swell) lebih tinggi dari pengembangan biasa (swelling) karena pada pengembangan bebas (free swell) tidak terdapat beban yang melawan pengembangan dari tanah lempung ekspansif.

Tabel 10. Hasil Pengujian Pengembangan Bebas (free swell)

\begin{tabular}{|l|l|l|l|}
\hline $\begin{array}{l}\text { Komposisi } \\
\text { Tanah }\end{array}$ & $\begin{array}{l}\text { Volum } \\
\text { e Awal } \\
(\mathbf{m l})\end{array}$ & $\begin{array}{l}\text { Volum } \\
\text { e Akhir } \\
(\mathbf{m l})\end{array}$ & $\begin{array}{l}\text { Free } \\
\text { Swell } \\
(\%)\end{array}$ \\
\hline Tanah asli & 42.5 & 72.5 & 70.59 \\
\hline $\begin{array}{l}\text { Tanah asli + } \\
\text { 8\% AAT + 4\% } \\
\text { Kapur }\end{array}$ & 45 & 62 & 37.78 \\
\hline $\begin{array}{l}\text { Tanah asli + } \\
8 \% \text { AAT + 6\% } \\
\text { Kapur }\end{array}$ & 65 & 33.33 \\
\hline $\begin{array}{l}\text { Tanah asli + } \\
\text { 8\% AAT + 8\% } \\
\text { Kapur }\end{array}$ & 65 & 55 & 22.22 \\
\hline
\end{tabular}

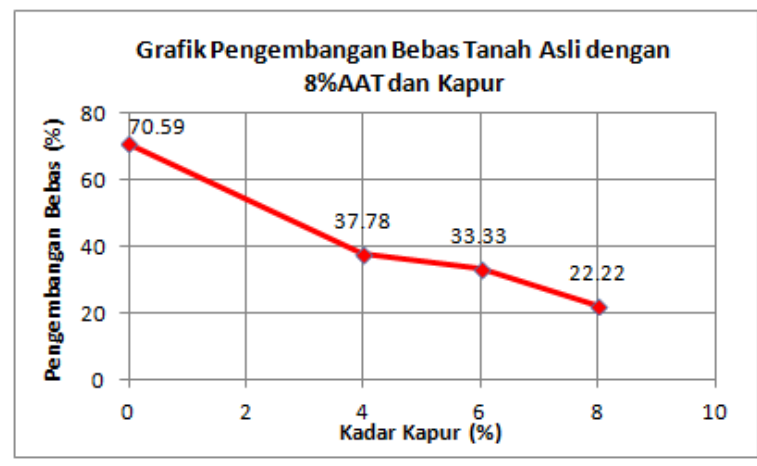

Gambar 10. Grafik Pengaruh Penambahan Kadar Abu Ampas Tebu 8\% dan Variasi Kadar Kapur terhadap Nilai Pengembangan Bebas (Free Sell)

\section{KESIMPULAN}

Setelah dilakukan analisa dan pemabahasan hasil penelitian, didapatkan beberapa kesimpulan sebagai berikut:

1. Dengan penambahan bahan campuran berupa abu ampas tebu dan kapur berpengaruh terhadap karakteristik tanah 
lempung ekspansif di Kec,Ngasem Bojonegoro, antara lain:

- Nilai specific gravity mengalami penurunan dibandingkan dengan tanah asli, yaitu sebesar 2,211 pada penambahan $8 \%$ abu ampas tebu dan kadar kapur $4 \%$.

- Nilai batas cair mengalami penurunan dibandingkan dengan tanah asli dari $104 \%$ menjadi $60,71 \%$ dengan tambahan kadar abu ampas tebu $8 \%$ dan kadar kapur 4\%. Untuk nilai batas plastis dan batas susut tanah mengalami peningkatan dibandingkan tanah asli, yaitu sebesar $50,72 \%$ pada campuran dengan kadar kapur $4 \%$ untuk batas plastis dan $47,74 \%$ pada campuran dengan kadar kapur $8 \%$ untuk batas susutnya. Sedangkan untuk nilai indeks plastisitasnya mengalami penurunan dibandingkan tanah asli, yaitu sebesar $9,99 \%$ pada campuran dengan kadar kapur $4 \%$.

- Nilai kadar air optimum mengalami peningkatan dibandingkan tanah asli dan nilai berat isi kering maksimum mengalami penurunan pada pemadatan.

2. Nilai CBR Unsoaked dan CBR Soaked yang didapatkan untuk tanah asli dengan penambahan bahan campuran abu ampas tebu $8 \%$ dan variasi kadar kapur mengalami peningkatan. Peningkatan nilai CBR maksimum didapatkan pada kondisi penambahan bahan campuran abu ampas tebu $8 \%$ dengan kadar kapur $6 \%$ kedalam tanah asli dengan nilai CBR Unsoaked sebesar 9,324\% dan nilai CBR Soaked sebesar 7,797\%. Nilai CBR ini mengalami peningkatan hingga $135,87 \%$ pada CBR Unsoaked dan 230,38\% pada CBR Soaked jika dibandingkan dengan nilai CBR tanah asli.

3. Seiring dengan banyaknya penambahan kadar kapur pada tanah lempung ekspansif nilai pengembangan dari tanah tersebut semakin kecil. Nilai pengembangan minimum didapatkan dari penambahan bahan campuran $8 \%$ abu ampas tebu dan $8 \%$ kadar kapur yaitu sebesar $0,1681 \%$. Nilai pengembangan tersebut mengalami penurunan hingga 97,28\% dari tanah asli.

4. Semakin banyaknya kadar kapur yang ditambahkan pada campuran, nilai pengembangan bebas semakin semakin menurun. Nilai pengembangan bebas (free swell) minimum diperoleh pada penambahan bahan campuran $8 \%$ abu ampas tebu dan $8 \%$ kadar kapur yaitu sebesar $22,22 \%$. Nilai pengembangan tersebut mengalami penurunan hingga 217,7\% dari tanah asli.

5. Pada prosentase bahan campuran $8 \%$ abu ampas tebu dan $4 \%$ kadar kapur, nilai $\mathrm{Cc}$ mengalami penurunan hingga $85,35 \%$ dari yang sebelumnya sebesar 0,658 menjadi 0,355. Artinya bahan-bahan campuran tersebut dapat memperkecil kemampuan tanah lempung ekspansif untuk memampat, sehingga penurunan (settlement) dari tanah tersebut juga semakin kecil.

\section{DAFTAR PUSTAKA}

[1] Sutikno dan Budi Damianto. Stabilisasi Tanah Ekspansif dengan Penambahan Kapur (Lime): Aplikasi pada Pekerjaan Timbunan. Jurnal Ilmiah Teknik Sipil Politeknik Negeri Jakarta.2009.

[2] Rahayu, S. Suparni(2009). Kapur Putih . From : http://www.chem-is- try.org/materi _kimia/kimia-industri/utilitas-pabrik/kapurputih/, 17 Desember 2014.

[3] Febra Ndaru W., Eko Andi S., Yulvi Zaika, As'ad Munawir, Arief Rachmansyah. Perbaikan Tanah Ekspansif Dengan Penambahan Serbuk Gypsum dan Abu Sekam Padi Untuk Mengurangi Kerusakan Struktur Perkerasan. Rekayasa Sipil Vol. 9 No. 3.2015.

[4] Das, Braja M. Mekanika Tanah 1 (PrinsipPrinsip Rekayasa Geoteknis). Diterjemahkan oleh Noor Endah dan Indrasurya B. Mochtar. Erlangga: Jakarta.1995.

[5] Budiman, N. Ari. Pengaruh Penambahan Abu Ampas Tebu Terhadap Sifat Fisik dan Sifat Mekanik Tanah Lempung Ekspansif. Jurnal Ilmiah Teknik Sipil Vol.17, No.1, Universitas Udayana, Bali.2013. 